\title{
Legal Aspects of Hotel Policy towards Employees Due to the Covid 19 Pandemic in Parapat
}

\author{
Imman Yusuf Sitinjak ${ }^{1}$, Rosita Nainggolan ${ }^{2}$ \\ ${ }^{1,2}$ Universitas Simalungun, Indonesia \\ immanjoes@gmail.com,rositanainggolan60@gmail.com
}

\section{Abstract}

This study aims to determine how the hotel policies in laying off employees are reviewed according to the labor law in Law No. 13 of 2003 and Civil Law in terms of work agreements. The interest of having a job is the most important interest of every society. Because by having a job, people have income to meet their daily needs. This study discusses the policy of the hotel to lay off employees while in the work agreement, employees have the right to pay that they must receive in accordance with the work contract. It is true that no one knows if the COVID 19 pandemic that attacks all countries in the world has had many adverse effects on society. One of the most important impacts is the decline in income and business due to government policies that require reducing the number of people gathering or creating crowds in Indonesia. As a result of this decreased income, employers made efforts to lay off employees to prevent their business from rolling down. However, this policy creates losses for employees who work in the place of business. The conclusion that can be drawn is a violation of the contents of the agreement if when laying off employees or workers but they do not give their rights, namely salary, because salary is the right of every employee who works, and when leaving but not returning to employ an employee where the contract is still valid it is a violation of the contents of the contract, except with the agreement and conditions to terminate the employee's unilateral contract with compensation for severance pay by the hotel. However, this will be difficult if the employees who are dismissed and not given a salary and who are not called back to work are employees who work under an oral agreement. Because there is no written agreement that is binding and proves what was agreed upon orally between the employee and the entrepreneur.
Keywords

impact of the covid 19 panderic, employment; hotel policy

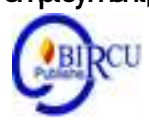

\section{Introduction}

Corona Virus Diseases 2019 or what is known as Covid-19 is a problem that has highlighted the attention of many people in various parts of the world. Since it was first discovered from a patient infected with Covid-19 in Wuhan, Hubei Province, China on December 8, 2019. The development of the health crisis which has an impact on the world economy has practically forced all countries in the world to retreat with strategic plans that had been originally set for then replaced by an emergency response policy by mobilizing all resources to deal with the Covid-19 outbreak. (Arfan et al, (2021) 
The large number of countries that experienced the Covid-19 case made the World Health Organization (WHO) raise the Covid-19 case from an epidemic to a pandemic (Ekarina, 2020). The rising status of Covid-19 from an epidemic to a pandemic has made many countries including Indonesia undertake various practices of protection and supervision of the region and human interaction in it with various mechanisms including; social distancing, physical distancing, regional quarantine to lockdown mechanisms. In Indonesia, in addition to the mechanism of social distancing and physical distancing, PSBB (Large-scale Social Limitation) for areas that are considered to have an emergency status are also stipulated. (Saleh and Mujahiddin, 2020)

Covid-19 can be transmitted very quickly from human to human, so that the number of positive cases of Covid-19 every day increases. Efforts made by the Indonesian government to stop the spread of Covid-19, by implementing a stay at home policy and health prevention. Prevention by maintaining health such as keeping a distance of at least 2 meters from each other, wearing masks, diligently to wash hands, and spraying disinfectants of each house, which is then followed by a policy of Large-Scale Social Restrictions (PSBB). (Ichsan et al, 2021).

The current Covid 19 pandemic is a very serious problem for every country, where the work mobility of all people in the world is blocked and they cannot carry out their usual activities. Likewise hotels in Parapat, when the implementation of the PSBB to prevent the spread of the Covid 19 disease, many hotel employees were dismissed by the hotel. This policy is taken by the hotel owner in accordance with government instructions and also the efforts of the hotel to reduce even greater losses, because they have to pay employee salaries while visitors are absent.

Whereas during the PSBB period, most of the employees who were sent home did not get a salary, because the salary was only given when the employees were already working, while when the PSBB period was over and entered the new normal period, employees who returned were employed but with a salary that was not in accordance with the work contract. it was agreed that the salaries of the employees were only a portion given each month until the financial situation of the hotel improved.

Seeing the existence of payroll as a right that is received by employees that must be given by the hotel becomes a serious problem which is no longer in accordance with the rights that must be given by the hotel based on an agreed upon agreement.

Based on the background that has been developed above, the researchers are interested in further research. The problems in this paper can be formulated in the form of the following main questions: How the hotel policy in laying off employees is reviewed according to the labor law in Law No. 13 of 2003 and Civil Law in terms of work agreements?

\section{Research Methods}

In this paper, the method used by the author in this discussion is Normative Juridical, namely an approach based on the main legal materials by examining theories, concepts, legal principles and statutory regulations related to this research. In this research, it is used by reading books and legal experts and regulations / laws to discuss writing problems in accordance with the theory and legal basis.

Solving a legal issue through legal research requires certain approaches as a basis for formulating appropriate arguments. There are various approaches in legal research, namely the statute approach, the case approach, the historical approach, the comparative approach, and the conceptual approach. 
In carrying out research on "Legal Aspects of Hotel Policy Towards Employees Due to the Covid 19 Pandemic in Parapat", it is necessary to use a conceptual approach, which is a type of approach in legal research that provides an analysis point of view of problem solving in legal research seen from the aspect of The legal concepts behind it, or even can be seen from the values contained in the normalization of a regulation in relation to the concepts used.

\section{Discussion}

In article 1 number 1 of law no. 13 of 2003 concerning Ketenagakerjaan states that employment is something related to labor before, during, and after the work period. In the Manpower Act, mostly discuss about labor law. Broadly speaking, the population of a country can be divided into two groups, namely workers and non-workers.

Employment itself is a relationship between employers as employers and workers as recipients of work in the company. Manpower law is a legal rule that regulates the work relationship between a worker or laborer and an employer or employer and with all the consequences that occur at work.

The definition of a company can be found in Law No. 3/1992 on company registration and in law No. 8/1997 on company documents. Entrepreneur is any individual or association or legal entity that runs a type of company. According to Article 1 point 5 of the Manpower Law, Entrepreneurs are:

1. Individuals, associations, or legal entities that run their own company;

2. an individual, an association, or a legal entity that independently runs a company that does not belong to him;

3. Individuals, associations, or legal entities that are in Indonesia representing companies as referred to in letters $a$ and $b$ which are domiciled outside the territory of Indonesia.

In article 1 point 2 of Law Number 13 of 2003 concerning manpower, the term labor has a general meaning, namely, every person who is capable of doing work to produce goods and services to meet the needs of himself or the community.

Employment law has the following elements.

1. A series of rules that are written and unwritten.

2. Regulate the incidence of employment relations between workers and employers or employers.

3. There are people working for and under other people for a fee as remuneration.

4. Regulating worker or labor protection, covering problems with illness, menstruation, pregnancy, childbirth, the existence of workers 'or laborers' organizations, and so on.

Labor law does not cover the following:

1. self-employment (work at your own responsibility or risk);

2. work performed for others on a voluntary basis;

3. work of a manager or representative of an organization or association.

The scope of employment is not narrow and simple. The reality in practice is very complex and multidimensional. Therefore, there is a point if the labor law does not only regulate work relations, but also includes arrangements outside of work relations, and it needs to be heeded by all parties and there is a need for third party protection, namely the ruler (government) if there are parties who are injured.

Some of the elements inherent in the term worker or laborer are as follows:

1. Everyone who works (labor force or not but must work)

2. Receiving compensation / wages as remuneration for the implementation of the work. 
In Law Number 13 of 2003 concerning Manpower that: A company is any form of business that is legal or not, owned by an individual, owned by an association, or owned by a legal entity, both private and state-owned, which employs workers or laborers by paying wages or other forms of reward.

Employers and workers are connected within the company through work agreements, where workers bind themselves with the company with the employer's consent to work for the company.

An employment relationship is basically a relationship between the worker and the employer after the existence of a work agreement, which is an agreement in which the one party worker binds himself to another party (in this case the employer to work / entrepreneur) with a wage and the employer declares his ability to employ workers. according to need by paying money.

Work relations occur based on two things, namely:

1. Based on the Civil Code (BW): The birth of a contractual legal relationship is due to an agreement or in other words the work relationship was born because of a work agreement.

2. Employment Relations According to Indonesian Regulations (According to Article 1 paragraph 15 of the Manpower Law): An employment relationship is a relationship between an entrepreneur and a worker / laborer based on a work agreement, which has elements of work, wages and orders. Based on the work relationship described above in the Manpower Law, a work relationship is a legal relationship that is born after a work agreement exists between a worker and an entrepreneur.

The right of an entrepreneur is something that must be given to an entrepreneur as a consequence of his workforce working for him or because of his position as an entrepreneur.

The entrepreneur's right is to receive the results of the work promised according to the worker's ability, which means:

1. Workers are required to do their own work not to be replaced by a third person other than with the employer's permission.

2. The workforce obeys the rules about doing work as well as the rules that are aimed at the company.

3. Manpower according to employer rules.

The general obligation of entrepreneurs as a result of the emergence of an employment relationship is to pay wages. Meanwhile, an additional obligation is to provide a certificate to the worker who on his own accord has the right to stop working in the company. Likewise, it can be said as other main obligations, namely, regulating work, arranging workplaces, keeping a wage book and holding a wage payment book.

The obligations of the recipient of the workforce, namely the workforce, are generally encapsulated in the rights of the employer, as well as the rights of workers in the obligations of the employer, in other words, if the contents contained in the work agreement show the obligations that must be fulfilled by the workforce, then the obligation is to the contrary for the entrepreneur is his right, and likewise if the contents contained in the work agreement indicate the obligations that must be fulfilled by the entrepreneur, then these obligations are the rights of the workforce.

A labor agreement is an agreement in which one party is obliged to bind himself to be under the orders of the other party, the employer, for a certain task to do work with a wage.

There are two types of work agreements, namely:

a. Oral: namely an agreement that is only made by a worker with an entrepreneur who has reached a work agreement and the terms related to a work agreement that is made orally.

b. Written: namely an agreement made by a worker with an entrepreneur who has reached a work agreement and the terms related to a work agreement made with a written letter of appointment signed by both parties. 
There are two kinds of work agreements in terms of time, namely:

a. Fixed-time work agreement (PKWT): A specified work agreement in accordance with a work agreement made in writing and based on a certain period of time or the completion of a certain job.

b. Unspecified Time Work Agreement (PKWTT): An indefinite work agreement is an agreement made in writing and based on an indefinite period of time in other words if a work agreement is reached between the employer and the worker and finally arrives at the signing of a work agreement. not certain, this worker is considered a permanent worker.

According to Djumadi, there are two possibilities regarding the termination of a work relationship:

1. By law, namely the expiration of the time or object that was agreed upon or agreed upon has passed.

2. Workers die with the exception of those who die from the employer, then the work agreement for a certain time does not end, that a work agreement for a certain time does not end even though the entrepreneur falls bankrupt.

\subsection{Forms of Hotel Policies for Employees Due to the Covid-19 Pandemic}

Hotel policies for employees due to the Covid-19 pandemic vary. The hotel policy in Parapat does not apply the same in every hotel, because there are various kinds of hotels in Parapat, ranging from large hotels that accommodate dozens of employees, large hotels with no more than 20 employees, large hotels with no more than 20 employees. also small hotels that use the hotel name but on a homely scale.

At the time of the announcement of the danger of covid-19, not all hotels immediately closed or stopped receiving visitors at the hotel. Most hotels still open their hotels for visitors who want to stay at the hotel.

For small hotels on a home scale, they do not feel afraid of the dangers of covid-19, because for them the inn is their livelihood so that the reception of visitors is still carried out. For several large hotels, there are some that still receive visitors, some are immediately stopping the reception of visitors. The implementation of stopping the acceptance of visitors is a rule established by the company.

The implementation of the PSBB itself is an implementation by the local government based on instructions set by the government. Not a few local governments have been slow to announce to their regions to implement the PSBB. This is because the implementation of the PSBB is left back to the regional head to implement it and how long the PSBB will take effect.

In Parapat, when the local government instructed the implementation of the PSBB, visitors were prohibited from coming to visit the Parapat area. But there are also some visitors who are not afraid and stay overnight at Parapat. They stay at hotels that are still receiving visitors.

For almost 3 months the activities at the parapat stopped due to the implementation of the PSBB. Until entering the new normal period, all hotels move slowly as usual, until now they have returned to normal with a very large number of visitors every weekend and during national holidays.

For employees, no one is sent home if it is in small home-scale hotels. Because they as owners, they are also workers who complement the needs of visitors and keep the facilities of their hotel rooms clean. Because most small hotels do not provide food, they only provide standard rooms and amenities such as rooms complete with beds, towels and bathrooms, as well as extra beds if needed.

Several large hotels that have employees of tens or even over a hundred have different policies with employees during the Covid-19 pandemic, starting from the implementation of 
the PSBB to the implementation of the current new normal period. This happened based on instructions from the company which made many employees, both permanent and contractual, were dismissed and even did not work at the hotel anymore.

There are several policies taken by the company, namely:

a. In April and May all employees are laid off

b. The majority of women who were sent home

c. Those who were sent home were not given any wages at all

d. In June the hotel employees were called back to work

e. Employees return to work as directed by the company and work mostly two weeks a month and pay is in accordance with the employee's time worked.

f. During the new normal period, all employees have been called back to work in July.

g. Payroll is not as usual, but the salary cut is not up to $50 \%$ of salary (because hotel visitors are not normal as usual to produce employee payroll needs).

At Niagara hotel, during the PSBB hotel period during the implementation of the PSBB until the new normal period, there were several policies taken by the company, namely:

a. During the time the PSBB Niagara Hotel was closed, only security guards worked.

b. All employees are both contracted and sent home until the new normal period to return to work.

c. Payroll for employees does not exist when the hotel is closed

d. When the hotel opened again, the employees were still called to work with only $50 \%$ of the working time a month and the salary was also only $50 \%$.

e. During the new normal period, employees who worked permanently with a working period of only $50 \%$ of the time worked in a month and only $50 \%$ were given a salary for those who were called back to work.

f. Extra Fee for those who work beyond $50 \%$ working limit

g. Some of the day and contract employees have returned to work

h. In August, $75 \%$ of the staff who were sent home were called back to work.

At the INNA Parapat Hotel, during the PSBB hotel period during the PSBB implementation until the new normal period, there were several policies taken by the company, namely:

a. The hotel has a policy set from the head office in accordance with the Directors Instruction No. 0001 / INS / DIRUT / HIN / IV / 2020 which contains:

a) Employing employees according to hotel needs during the Covid-19 Pandemic

b) For contract employees (PKWT) who did not enter with hotel needs employees (Skeleton Team) during the Covid-19 Pandemic period were sent home

c) Permanent employees (PKWTT) who are not on duty and are not included in the hotel needs employees will be closed without reducing their leave allowance

d) For PKWT employees who have been dismissed, they will be reinstated in accordance with the company's future business conditions.

e) For PKWT employees whose contracts are due in April to June 2020, they will not be extended except for employees who are in hotel needs.

f) Payments are subject to postponement of employee benefits such as, but not limited to, annual and long leave allowances, replacement of eyeglass facilities, and period of service pay.

Employees who are reinstated during the new normal are adjusted to the needs of the hotel. There are also several large hotels that have made a policy of laying off employees on a large scale, by employing only part of the employees with full work but partially cut wages. This cannot be explained in the research because there is no research permit from the hotel. 
So it can be concluded based on the above discussion that the form of hotel policies for employees due to the Covid-19 pandemic is that most large hotels take the policy of laying off employees by laying off employees and cutting wages unilaterally according to working time. During the time of being laid off, no salary was given, it was different from the INNA Parapat hotel which postponed some of the benefits that would be paid later after the pandemic period had improved. And for small hotels there is no one to lay off employees because they are the owners who work to take care of the hotel.

\subsection{Protection of the Hotel for Employees Due to Being Laid off in the Middle of the Covid-19 Pandemic}

Protection is all forms of effort given to help or prevent things that are not desired. protection according to KBBI can be equated with the term protection, which means the process or act of protecting. The definition of legal protection is a protection given to legal subjects in the form of legal instruments that are repressive or preventive in nature.

According to Setiono, legal protection is an act or effort to protect society from arbitrary actions by a ruler who is not in accordance with the rule of law, to create order and tranquility so as to enable humans to enjoy their dignity as humans. According to Muchsin, legal protection is an activity to protect individuals by harmonizing the relationship of values or principles that are manifested in attitudes and actions in creating order in the social life between humans.

Juridically, in Article 5 of Law Number 13 Year 2003 concerning Manpower, which provides protection that; Every worker has the same opportunity without discrimination to get a job". Article 6 of Law Number 13 Year 2003 concerning Manpower, explains that; "Every worker / laborer has the right to receive equal treatment without discrimination from employers". This makes it clear that it is obligatory for employers to grant rights and obligations to workers or laborers regardless of gender, ethnicity, race, religion, skin color, and political orientation".

Labor protection is part of the entrepreneur to protect his workers from things that are not desirable, both in the work agreement and at work. According to Abdul Hakim in Yusuf Subkhi, labor protection is intended to ensure a harmonious work relationship system without being accompanied by pressure from the strong to the weak.

According to Soepomo in Abdul Khakim states that labor protection can be divided into 3 (three) types, namely:

1. Economic protection, namely protection of workers in the form of sufficient income, including if the worker is unable to work against his will.

2. Social protection, namely protection of workers in the form of occupational health insurance, freedom of association and protection of the right to organize.

3. Technical protection, namely protection of workers in the form of work security and safety.

The policy to lay off employees is decided by conducting deliberations with all employees. Because the impact of the Covid 19 pandemic was the issuance of policies to carry out PSBB in the regions. PSBB policy that requires companies to stop their activities, including hospitality in Parapat.

Many have misunderstood the concept of laying off by unilateral contract termination / layoffs. In terms of laying off employees, it is in the interest of protecting the health of the company and employees. Meanwhile, the unilateral contract termination / dismissal is to unilaterally end the employee's working relationship by the entrepreneur. Regarding layoffs, the implementation of layoffs has been regulated in Law Number 13 of 2003 concerning Manpower, which is based on article 1 number 25 of the Manpower Law, which is the termination of the employment relationship due to certain things that result in the termination 
of rights and obligations between workers / labor and entrepreneurs. In the Manpower Act, layoffs are regulated in the provisions of articles 150-172, which basically means that employers cannot carry out layoffs arbitrarily for their workers.

During the current Covid19 pandemic, for hotel employees in Parapat, employers did not terminate employment, but instead lay off employees. So that there is no termination of employment. However, employee payroll is in the spotlight on the problem of laying off employees, is there a violation or is there protection from the company for the policy of laying off hotel employees. Regarding laying off employees there are several problems, such as in hotels that have many employees, how they faced the Covid 19 pandemic at the time of the PSBB, while they did not work because they were sent home and there was no salary for daily life.

This is indeed a difficulty for both parties, namely entrepreneurs and the community. Employers also suffer losses due to decreased income because there are no visitors due to PSBB, while employers have to think about the salaries of their employees. Employees also experience the same thing, where employees have to be sent home due to PSBB and the calculation of pay is based on attendance, so when they are sent home automatically there is no salary they get while they are sent home.

The protection provided by hotels in Parapat for employees who are sent home varies, namely:

1. Hotel Niagara Parapat provides protection for employees of the BPJS for employee health. Every employee continues to receive basic food assistance during the PSBB period due to the Covid pandemic. No assistance other than that was provided during the PSBB period. Meanwhile, a form of labor protection for employees is that employees will be re-employed gradually until $100 \%$ work entirely in line with the improvement in company finances due to the impact of the Covid-19 Pandemic.

2. Hotel Danau Toba International Cottage Parapat provides protection for employees, only covers employee insurance by the company during the PSBB period and is sent home. The employees who were sent home received basic food assistance for the employees during the PSBB. Labor protection for employees are employees who are sent home and re-employed in July after entering the new normal period, but with the stipulation that remuneration is in accordance with working hours. So that it allows employees to only work part time with half the payroll until the hotel company conditions improve and can hire full time employees.

3. Hotel INNA Parapat provides protection for employees during the PSBB period, namely by providing salaries and allowances for permanent employees who are sent home, while for contract employees only benefits are given for BPJS health and BPJS Ketenagakerjaan. After entering the new normal period, contract employees will be rehired partially according to the needs of employees at the hotel.

So it can be concluded that the protection provided by the hotel for employees during the Covid 19 pandemic is that the hotel as a company provides protection for employees by continuing to pay for employee health insurance, and providing basic necessities due to the PSBB period. Meanwhile, not all hotels provide salaries to employees during the PSBB period, especially to PKWT employees or contract employees. However, the hotel is trying to re-hire contract employees after entering the new normal period so that employees can work again as the hotel finances improve in the parapat. 
3.3 Hotel Policy in Laying off Employees, Assessed According to Manpower Law in Law No. 13 of 2003 and Civil Law in Terms of Employment Agreements

There are no workers who want to be laid off, because for workers the income is used to meet their daily needs. Indeed, the PSBB policy resulted in dismissal of employees, because hoteliers also did not have the advantage or capital to pay their employees' salaries from managing their hotels.

A business without results is the same as going bankrupt so that the policy of every hotel in laying off employees during the PSBB Pandemic Covid 19 is the only way to prevent hotel entrepreneurs from going out of business. For this reason, the policy to lay off employees must be based on a deliberation mechanism, not by making unilateral decisions.

If studied under civil law, that promises must be kept where what is stated in the work contract made and agreed upon by the hotel must be fulfilled under any circumstances. And in the labor law, the hotel is obliged to protect the rights of employees in accordance with labor laws, both from health, to wages. Because the policy of laying off employees is a policy of the hotel, not the desire of good employees. So that there is no reason for the hotel not to give employees the rights even though Article 93 (1) of the Manpower Law states "Wages are not paid if the worker / laborer does not work". Because laying off is not because of the fault of the employees but to protect the hotel business from going out of business.

\section{Conclusion}

The hotel policy in laying off employees is reviewed according to the labor law in Law No. 13 of 2003 and Civil Law in terms of employment agreements is a violation of the contents of the agreement if when you lay off employees or workers but do not give their rights, namely salary, because salary is the right of every employee who works, and when they leave but do not return to employ employees where the contract is still valid is a violation of the contents of the contract, except with the agreement and conditions to terminate the employee's contract unilaterally with compensation for severance pay by the hotel However, this will be difficult if the employees who are dismissed and not given a salary and who are not called back to work are employees who work under an oral agreement.

\section{References}

Arfan, S, et al. (2021). Responsivity of Public Services in Indonesia during the Covid19 Pandemic. Budapest International Research and Critics Institute-Journal (BIRCIJournal). P. 552-562

Djumadi. (2008). Hukum Perburuhan Perjanjian Kerja, PT. Grafindo Persada, Jakarta.

Faisal Salam. Moch. (2009). Penyelesaian Perselisihan Perburuhan Industrial di Indonesia, Mandar Maju, Bandung.

Husni. Lalu. (2007). Pengantar Hukum Ketenagakerjaan Indonesia, PT. Raja Grafindo Persada, Jakarta, Asikin. Zainal. Et al, Pengantar Hukum Perusahaan, Prenadamdia Group, Jakarta, 2016

Ichsan, R. et al. (2020). Determinant of Sharia Bank's Financial Performance during the Covid19 Pandemic. Budapest International Research and Critics Institute-Journal (BIRCIJournal). P. 298-309

Khakim. Abdul. (2003). Pengantar Hukum Ketenagakerjaan Indonesia, PT. Citra Aditya, Bandung.

Midah Agus. (2010). Hukum Ketenagakerjaan Indonesia Dinamika Dan Kajian Teori, Ghalia Indonesia, Bogor. 
Muchsin. (2003). Perlindungan dan Kepastian Hukum bagi Investor di Indonesia, Disertasi S2 Fakultas Hukum, Universitas Sebelas Maret, Surakarta.

Saleh, A. and Mujahiddin. (2020). Challenges and Opportunities for Community Empowerment Practices in Indonesia during the Covid-19 Pandemic through Strengthening the Role of Higher Education. Budapest International Research and Critics Institute-Journal (BIRCI-Journal). P. 1105-1113.

Setiono. (2004). "Rule of Law", Disertasi S2 Fakultas Hukum, Universitas Sebelas Maret, Surakarta.

Subhan. M.Hadi., Hukum Kepailitan Prinsip Norma dan Praktek di Peradilan, Kencana, Jakarta.

Wahyudi. Eko. (2016). Hukum Ketenagakerjaan, Cetakan Pertama, Sinar Grafika, Jakarta.

Yusuf Subkhi. (2012). Perlindungan Tenaga Kerja Alih Daya (Outsourcing) Perspektif Undang-undang No. 13 Taun 2003 Tentang Ketenagakerjaan dan Hukum Islam, UIN Maliki Malang, Malang. 